Динис Г.Г., кандидат юридичних наук, професор, завідувач кафедри міжнародного права ДВНЗ «Ужгородський національний університет» (м. Ужгород, Украӥна)

\title{
ЮРИДИЧНИЙ МЕХАНІЗМ РЕГУЛЮВАННЯ ОСНОВНИХ НАПРЯМІВ ТРАНСКОРДОННОГО СПІВРОБІТНИЦТВА НА НОВОМУ СХІДНОМУ КОРДОНІ ЄС
}

У статті досліджуються проблеми інституціонального $i$ організаційно-правового забезпечення транскордонного співробітництва на новому східному кордоні СС.

Ключові слова: транскордонне співробітництво, правове регулювання, міжнародні транскордонні відносини, Свропейський Союз.

The article examines the problems of institutional and organizational and legal provision of cross-border cooperation on the new EU eastern border.

Key words: cross-border cooperation, legal regulation, international crossborder relations, European Union.

Еволюційний розвиток міжнародних європейських транскордонних відносин другої половини XX ст. - початку XXI ст. пов'язаний із макроглобалізаційними та інтеграційними процесами, розширенням Свропейського Союзу, які супроводжуються відповідними трансформаційними змінами на рівні міжнародного європейського правопорядку та національних правопорядків суверенних держав.

Наукові та практичні дослідження основних аспектів цієї проблематики свідчать про наявність широкого діапазону суперечливих правових, політичних, економічних оцінок, а також принципових доктринальних розбіжностей щодо кваліфікації статусу міжнародних транскордонних відносин у системі міжнародних відносин та прогностичних наслідків можливих результатів та наслідків цього феномену у новітній системі європейського правопорядку [1-20].

Разом 3 тим, проблема юридичних засад міжнародних європейських транскордонних відносин не становила спеціального предмета правових досліджень, що формує сферу особливих інтересів для поглибленого вивчення транскордонних правовідносин з точки зору міжнародного права.

Проблема інституціонального і організаційно-правового забезпечення транскордонного співробітництва на східному кордоні Європейського Союзу характеризується суттєвими differentia specifica, які визначаються саме статусом України - суверенного учасника транскордонних відносин на Сході ЄC. Україна, будучи учасником Свропейської рамкової конвенції про транскордонне співробітництво між територіальними общинами або властями (ETS No106 - Мадрид, 21 травня 1980 р.) на відміну від сусідніх 
східноєвропейських держав de-yure не $\epsilon$ учасником європейського інтеграційного утворення - СС і відповідних міжнародних правовідносин.

В правовому плані такий процес передбачає не тільки правові можливості формування ефективного юридичного механізму транскордонного співробітництва прикордонних держав, але одночасно обумовлює необхідність адаптації законодавства України до правових стандартів системи права $\mathrm{CC}$ - acquis communautaire $\mathrm{CC}$.

У зв'язку з цим виникає питання про юридичні рамкові основи механізму транскордонного (прикордонного) співробітництва на східному кордоні СС. Аналіз юридичної основи міжнародних транскордонних відносин (співробітництва) методологічно обумовлює необхідність дослідження інституціонального i організаційно-правового механізму транскордонного співробітництва на двох ієрархічних рівнях - на рівні міжнародного права та національного законодавства, які $є$ самостійними підсистемами i разом 3 тим взаємодоповнюють та гармонізують функціонування відповідних підсистем механізму правового регулювання.

Як загальна юридична формула стаття 2 Європейської рамкової конвенції про транскордонне співробітництво між територіальними общинами або властями визначає, що «транскордонне співробітництво здійснюється в межах компетенції територіальних общин або властей, визначеної внутрішнім законодавством. Межі та характер такої компетенції цією Конвенцією не змінюються». Більше того, підпункт 2 ст. 2 формулює міжнародно-правову норму про те, що «для цілей цієї Конвенції вислів «територіальні общини або власті» означає общини, власті або органи, які здійснюють місцеві або регіональні функції та визнаються як такі внутрішнім законодавством кожної держави» [21].

Отже, у відповідності до міжнародного договору (конвенції) правові умови імплементації транскордонних правовідносин визначаються внутрішнім законодавством учасника конвенції і $є$ предметом внутрішньої компетенції держави-учасниці відносин транскордонного співробітництва.

На рівні міжнародного права юридичну основу транскордонних відносин створюють багатосторонні та двосторонні міжнародні договори (конвенції, протоколи). Це, в першу чергу, - вищезгадана діюча Європейська рамкова конвенція про транскордонне співробітництво між територіальними общинами або властями; валідарний (діючий) Додатковий протокол до Свропейської рамкової конвенції про транскордонне співробітництво між територіальними общинами або властями (Страсбург, 9 листопада 1995 р.); Другий протокол до Свропейської рамкової конвенції про транскордонне співробітництво між територіальними общинами або властями (5 травня 1998 р.); Протокол № 3 до Європейської рамкової конвенції про транскордонне співробітництво між територіальними общинами або властями стосовно об'єднань єврорегіонального співробітництва (ОСС) не вступив у силу. 
Переваги цих міжнародних договорів на практиці полягають в тому, що вони $є$ основою міжнародно-правового механізму регулювання міжнародних відносин на двосторонньому міжурядовому та багатосторонньому рівнях, спрямованого на забезпечення правового регулювання транскордонного i міжрегіонального співробітництва, учасниками яких $є$ як юридичні, так i фізичні особи. Транскордонне співробітництво, засноване на таких угодах, може здійснюватися також між громадськими організаціями на різних рівнях (наприклад, державами і регіонами, регіонами і провінціями, регіонами i муніципалітетами, місцевими властями і міжнародними організаціями), може стосуватись різних сфер співробітництва, включаючи політичну, економічну, торговельну, культурну та наукову.

У зв'язку з цим виникає питання стосовно врегулювання політичного та правового статусу кордонів на двосторонньому рівні на східному кордоні Європейського Союзу. Який статус міждержавних угод про правовий режим кордонів?

Станом на 1 травня 2012 р. міждержавні угоди про державні кордони укладені між Україною та Республікою Польща, Словацькою Республікою, Угорщиною, Румунією (табл. 1).

Таблиия 1

\begin{tabular}{|c|c|c|c|c|}
\hline № & Держнава & $\begin{array}{c}\text { Наявність м/договору } \\
\text { про правовий режсим } \\
\text { державного кордону }\end{array}$ & $\begin{array}{c}\text { Наявність інших } \\
\text { м/договорів, протоколів, } \\
\text { актів }\end{array}$ & $\begin{array}{c}\text { Наявність рішень } \\
\text { міжнародного суду } \\
\text { стосовно правового } \\
\text { режиму державного } \\
\text { кордону }\end{array}$ \\
\hline 1. & $\begin{array}{c}\text { Республіка } \\
\text { Польща }\end{array}$ & $\begin{array}{c}\text { Договір між } \\
\text { Україною і } \\
\text { Республікою } \\
\text { Польща про } \\
\text { правовий режим } \\
\text { українсько- } \\
\text { польського } \\
\text { державного } \\
\text { кордону, } \\
\text { співробітницто і } \\
\text { взаємодопомогу з } \\
\text { прикордонних } \\
\text { питань (підписаний } \\
\text { 12.01. 1993 р.). } \\
\text { (набув сили } \\
\text { 27.10.1993 р.). } \\
\text { Угода між Урядом } \\
\text { України та Урядом } \\
\text { Польщі про } \\
\text { міжрегіональне } \\
\text { співробітництво } \\
\text { (дата підписання: } \\
\text { 24.05.1993, } \\
\text { дата набуття }\end{array}$ & $\begin{array}{c}\text { Протокол про } \\
\text { Прикордонний знак } \\
\text { «Кременець», } \\
\text { який встановлено } \\
\text { на стику } \\
\text { державних } \\
\text { кордонів } \\
\text { України, } \\
\text { Республіки } \\
\text { Польща та } \\
\text { Словацької } \\
\text { Республіки } \\
\text { (підписаний } \\
\text { 14.04. } 2005 \text { р.). }\end{array}$ & відсутні \\
\hline
\end{tabular}




\begin{tabular}{|c|c|c|c|c|}
\hline & & \begin{tabular}{|c|} 
чинності: \\
27.10.1993). \\
Договір між Україною \\
і Словацькою \\
Республікою про \\
режим українсько- \\
словацького \\
державного \\
кордону, \\
співробітництво і \\
взаємодопомогу з \\
прикордонних \\
питань (підписаний \\
14.10 .1993 р.)
\end{tabular} & & \\
\hline 2. & $\begin{array}{l}\text { Словацька } \\
\text { Республіка }\end{array}$ & \begin{tabular}{|c|} 
Договір між \\
Україною і \\
Словацькою \\
Республікою про \\
режим українсько- \\
словацького \\
державного \\
кордону, \\
співробітницто і \\
взаємодопомогу з \\
прикордонних \\
питань (підписаний \\
14.10 .1993 р.)
\end{tabular} & $\begin{array}{c}\text { Протокол про } \\
\text { прикордонний знак } \\
\text { „Кременець”, який } \\
\text { встановлено на } \\
\text { стику держав- } \\
\text { них кордонів } \\
\text { України, Республіки } \\
\text { Польща та } \\
\text { Словацької } \\
\text { Республіки } \\
\text { (підписаний } \\
\text { 14.04. } 2005 \text { р.). }\end{array}$ & відсутні \\
\hline 3. & $\begin{array}{c}\text { Угорська } \\
\text { Республіка }\end{array}$ & \begin{tabular}{|c|} 
Договір між \\
Україною і \\
Угорською \\
Республікою про \\
режим українсько- \\
угорського \\
державного кордону, \\
співробітництво і \\
взамодопомогу з \\
прикордонних \\
питань (підписаний \\
15.05 .1995 р.). \\
\end{tabular} & & відсутні \\
\hline 4. & Румунія & \begin{tabular}{|c|} 
Договір між \\
Україною і \\
Румунією про режим \\
українсько- \\
румунського \\
державного \\
кордону, \\
співробітництво та \\
взаємну \\
допомогу з \\
прикордонних \\
питань (підписаний \\
17.06. 2003 р.). \\
\end{tabular} & & \begin{tabular}{|} 
Рішення Міжнародного \\
суду \\
ООН з питань \\
делімітації \\
континентального \\
шельфу та \\
виключних \\
економічних \\
зон України і Румунії у \\
Чорному \\
морі (3 лютого \\
2009 р.).
\end{tabular} \\
\hline
\end{tabular}


Укладені договори про державні кордони України 3 Російською Федерацією, Республікою Білорусь, а також з Республікою Молдова.

Залишаються неврегульованими питання делімітації та демаркації кордонів з Російською Федерацією, Республікою Молдова (частина/ сегмент Придністров'я) (табл. 2).

3 дати проголошення незалежності України у міжнародних відносинах із сусідніми державами проблема врегулювання політичного та правового статусу державних кордонів у формі міждержавних договорів займає одне із центральних місць у системі координат міжнародних відносин України 3 прикордонними державами.

\begin{tabular}{|c|c|c|c|c|}
\hline № & Держкава & $\begin{array}{c}\text { Наявність } \\
\text { м/договору } \\
\text { про правовий } \\
\text { режжим } \\
\text { держсавного } \\
\text { кордону }\end{array}$ & $\begin{array}{l}\text { Наявність інших } \\
\text { м/договорів, } \\
\text { протоколів, актів }\end{array}$ & $\begin{array}{c}\text { Наявність рішень } \\
\text { міжннародного суду } \\
\text { стосовно правового } \\
\text { режсму державного } \\
\text { кордону }\end{array}$ \\
\hline 5. & $\begin{array}{l}\text { Російська } \\
\text { Федерація }\end{array}$ & \begin{tabular}{|c|} 
Договір між \\
Україною і \\
Російською \\
Федерацією про \\
українсько- \\
російський \\
державний \\
кордон (підписаний \\
28.01. 2003 р.). \\
\end{tabular} & & відсутні \\
\hline 6. & $\begin{array}{c}\text { Республіка } \\
\text { Білорусь }\end{array}$ & \begin{tabular}{|c|} 
Договір між \\
Україною і \\
Республікою \\
Білорусь про \\
державний кордон \\
(підписаний \\
12.05 .1997 р.). \\
\end{tabular} & & відсутні \\
\hline 7. & \begin{tabular}{|} 
Республіка \\
Молдова та \\
Придністров'я \\
(невизнана \\
Придністровсь \\
ка \\
\\
Молдавська \\
Республіка (ПМР).
\end{tabular} & $\begin{array}{l}\text { Договір між } \\
\text { Україною і } \\
\text { Республікою } \\
\text { Молдова про } \\
\text { державний } \\
\text { кордон } \\
\\
\text { (підписаний } \\
\text { 18.08.1999). }\end{array}$ & \begin{tabular}{|c|} 
Угода між урядами \\
України і \\
Молдови про \\
співпрацю \\
стала початком \\
процесу делімітації \\
українсько- \\
молдовського \\
державного кордону \\
(11. 1994 р.).
\end{tabular} & відсутні \\
\hline
\end{tabular}


Таким чином, станом на 1 травня 2012 р. статус укладених міждержавних угод про державні кордони України з Республікою Польща, Словацькою Республікою, Угорщиною, Румунією свідчить про певний рівень стабілізації та врегулювання політичних і правових складових міждержавних відносин країн, що мають спільні державні кордони і є правовою основою міжнародних транскордонних відносин та співробітництва.

Разом 3 тим не завершено делімітацію континентального шельфу та виключних економічних зон України і Румунії в Чорному морі. 19 листопада 2004 року румунська сторона подала заяву до Міжнародного суду ООН щодо делімітації континентального шельфу та виключних економічних зон України і Румунії у Чорному морі.

3 лютого 2009 року Міжнародний суд ООН ухвалив рішення у справі делімітації континентального шельфу та виключних економічних зон України і Румунії у Чорному морі.

Згідно з ним, острів Зміїний було визнано островом 3 територіальним морем у 12 морських миль. У тому ж судовому рішенні було визначено лінію розмежування виключних економічних зон між Україною та Румунією, що стала компромісом між румунською та українською позиціями.

Політичний та правовий статус кордонів між Україною і Російською Федерацією, Білоруссю, а також із Республікою Молдова та Придністров'ям характеризується своїми особливостями.

Стосовно державних кордонів із Російською Федерацією:

a) незавершена делімітація та демаркація державного сухопутного кордону 3 Росією; б) у переговорному процесі перебуває проведення делімітаційних та демаркаційних робіт в акваторії Азовського моря й Керченської протоки.

12 травня 1997 року підписано договір між Україною і Республікою Білорусь про державний кордон. Названий Договір ратифіковано Верховною Радою 18 липня 1997 року (Закон України від 18 липня 1997 року № 491/97-вр). Національними Зборами Республіки Білорусь до цього часу договір про кордон не ратифіковано.

У зв’язку з цим демаркацію кордону на місцевості неможливо провести. Міжнародно-правовою основою двостороннього врегулювання політичного та правового статусу кордонів України з Російською Федерацією, Білоруссю та Республікою Молдова є такі міжнародні угоди: Мінська багатостороння угода щодо утворення Співдружності Незалежних Держав (СНД) містить положення про взаємне визнання і поважання територіальної цілісності країн-учасниць Співдружності, недоторканності їх кордонів. У заяві Верховної Ради України 20 грудня 1991 р. 3 приводу Угоди про Співдружність Незалежних Держав зазначалося: «Кордон між Україною - 3 одного боку, та Росією і Білоруссю - 3 іншого, є державним кордоном України, який $є$ недоторканним. Лінія його проходження, визначена 
Договором між Україною і Росією 1990 р., лишається незмінною, незалежно від того, чи є Україна стороною Угоди, чи ні» [22].

Меморандум про співробітництво в охороні державних кордонів Республіки Білорусь, Російської Федерації й України, підписаний главами держав у Москві 15 квітня 1994 р. Спільна заява підтверджувала готовність продовжити роботу з договірно-правового оформлення своїх державних кордонів.

Політичний та правовий статус кордонів між Україною та Республікою Молдова визначається, в першу чергу, наявністю Придністровського конфлікту (рум. Conflictul din Transnistria) - конфлікту, що виник на початку 1990-их між центральною владою Молдови та самопроголошеною Придністровською Молдовською Республікою.

Правові основи міжнародних відносин України і Республіки Молдова були сформовані Договором про добросусідство, дружбу та співробітництво, підписаним в Кишиневі 23 жовтня 1992 р. та Договором про співробітництво на період 1998-2007 рр. від 23 жовтня 1998 р.

Укладена в листопаді 1994 р. угода між урядами України і Молдови про співпрацю 3 прикордонних питань стала основою початку процесу делімітації українсько-молдовського державного кордону.

Таким чином, в цілому у питаннях про українсько-молдовський кордон досягнуті домовленості. Делімітацію державного кордону між Україною i Республікою Молдова завершено, підписано Договір між Україною i Республікою Молдова про державний кордон, Договір ратифіковано законом за № 1633-III (1633-14) від 06.04.2000.

На сьогодні неузгодженим залишається питання проведення демаркації центральної ділянки українсько-молдовського державного кордону (Придністровський сегмент).

Особливу увагу привертає проблема національного законодавства 3 питань правового регулювання транскордонного співробітництва. Україна прийняла: а) Закон України «Про транскордонне співробітництво» від 24.06 .2004 р. [23]; б) Концепцію від 15.09.2010 № 1838-р «Про схвалення Концепції держаної програми розвитку транскордонного співробітництва на 2011-2015 роки» [24]; в) Закон України «Про місцеве самоврядування» (від 21.05 .1997 р.) [25]; д) Закон України «Про місцеві державні адміністрації в Україні» (від 09.04.1999) [26]. Аналіз свідчить про те, що практично закон декларує високі цілі транскордонного співробітництва, надання повноважень місцевим органам виконавчої влади, органам місцевого самоврядування у сфері транскордонного співробітництва, а також законодавчого врегулювання питань фінансової підтримки розвитку транскордонного співробітництва. Закон відповідає вимогам регулювання законодавства Європейського Союзу або норм і принципів системи ГАТТ/СОТ. Разом з тим з практичної точки зору законодавство потребує створення прагматичних 
організаційно-правових та інституційних механізмів правового регулювання прикордонних відносин на інституціональному рівні.

Матеріальні норми Закону носять суто декларативний характер i не створюють юридичних основ для формування організаційно-правового i інституціонального механізму.

Аналіз правового статусу транскордонного співробітництва східноєвропейських держав, що мають спільні кордони, свідчить на користь пріоритетності створення концептуально оновлених ефективних організаційно-правових та інституційних механізмів, включаючи єврорегіони для здійснення транскордонного співробітництва як складової регіональної політики в Україні.

На наш погляд, вирішення проблеми формування організаційноправових та інституційних ефективних механізмів транскордонного співробітництва у юридичному плані пов’язано з реформуванням органів місцевого самоврядування та перерозподілу обсягу повноважень щодо транскордонного співробітництва між центральними владними структурами на користь територіальних общин або місцевих влад.

У цьому зв’язку практичне значення для регулювання транскордонних правових відносин має можливість використання модельних договорів, які розроблені під егідою Ради Свропи для потреб регіональних і місцевих влад і закріплені у Додатковому Протоколі (ETS No 159, Strasbourg, November, 1995) до Свропейської рамкової конвенції про транскордонне співробітництво між територіальними общинами або властями. В наявності $є$ п’ять типових моделей міждержавних угод та шість типових моделей угод консультативного характеру, в яких зазначається різний ступінь централізації i відмінностей в адміністративних структурах країн-учасниць транскордонного співробітництва, які пристосовані до потреб регіональних і місцевих влад. Перша група стосується моделі міждержавних угод щодо: а) сприяння транскордонному співробітництву; б) регіональних транскордонних консультацій; в) місцевих транскордонних консультацій; г) договірного транскордонного співробітництва між місцевими владами; д) органів транскордонного співробітництва між місцевими властями.

Друга група угод стосується: а) угод, статутів i контрактів між місцевими властями: б) угоди про утворення консультативної групи між місцевими владами; в) угоди про координацію в управлінні транскордонними місцевими громадськими справами; г) угоди про утворення приватноправових транскордонних асоціацій; д) угоди про утворення адміністративних органів для транскордонного співробітництва між місцевими владами [27].

Але проблема полягає в тому, що адміністративно-територіальні одиниці на рівні областей, країв, повітів держав на східних кордонах ЄС Угорщини, Румунії, Словаччини, Польщі, України, Молдови - згідно 3 національним законодавством не наділені законодавчими повноваженнями 
укладати міжнародні договори або квазіміжнародні договори 3 питань транскордонного співробітництва (такими повноваженнями по відношенню до певних видів міжнародних договорів наділені кантони Швейцарії та землі Німеччини).

На практиці (de-facto) має місце укладення численних договорів, угод про співробітництво прикордонних територій (адміністративнотериторіальних одиниць). Наприклад, Рамкова угода про міжрегіональне співробітництво між Закарпатською областю України і Кошицьким краєм Словацької Республіки (1999 р.), Угода про співробітництво між Пряшівським урядом (Словацька Республіка) i Закарпатською обласною державною адміністрацією (2000 р.), Угода про IНTЕРРЕГIО - про трілатеральне співробітництво Закарпатської області (Україна), СатуМарського повіту (Румунія) та області Саболч-Сатмар-Берег (Угорщина) (2000 р.), Угода між Закарпатською обласною державною адміністрацією (Україна) та Підкарпатським воєводством (Польща) (2002р.); Угода між Ужгородською міською радою (Україна) та органами місцевого самоврядування міст Міхайловце, Кошице (Словаччина), Ніредьгаза, Бейкешчаба (Угорщина), Ярослав (Польща), Чеська Ліпа (Чеська Республіка) та ін.

В юридичному плані вищеназвані угоди не створюють de-jure міжнародно-правових зобов'язань. Підставою для такого lex opinion $\epsilon$ нормативні положення Свропейської Рамкової Конвенції про транскордонне співробітництво між територіальними общинами або властями згідно 3 вимогами національного законодавства держав, що мають спільні кордони. Це означає відсутність будь-яких правових зобов'язань і прав у цій сфері, відповідно - цілісного правового механізму інституціонального i організаційно-правового забезпечення єврорегіонального співробітництва.

Прогнозуючи формування юридичного механізму як правових засад підвищення ефективності основних напрямів транскордонного співробітництва на новому східному кордоні ЄС щодо України, можливий наступний сценарій: еволюційно розвивається природний процес державотворення України i, відповідно, відбувається формування статусу України у сучасній системі європейських міждержавних відносин 3 відповідними внутрішніми структурними й інституційними реформами i перетвореннями у політичній, економічній, правовій та соціальній сферах, спрямованих на досягнення відповідності правової системи України правовим стандартам acquis communautaire $\mathrm{CC}$.

Сучасна практика здійснення транскордонного співробітництва свідчить про нові виклики та загрози на новому східному кордоні СС: нелегальна міграція, торгівля людьми, контрабанда, перевезення наркотиків і зброї. У цьому зв'язку ефективне транскордонне співробітництво потребує скоординованої державної політики щодо викликів та загроз глобального i 
регіонального характеру, а також достатньо прогнозованих програм практичних дій з державами-членами СС, що мають спільні кордони.

У контексті сформульованих позицій, на наш погляд, ієрархічний рівень євроінтеграційної складової наближення України до Європейського Союзу є визначальною системною умовою створення реального інституціонального і організаційно-правового забезпечення транскордонного співробітництва України з сусідніми державами.

Таким чином, аналіз правових аспектів теорії і практики міжнародного транскордонного співробітництва на східному кордоні Свропейського Союзу свідчить про пріоритетність формування юридичного механізму регулювання для ефективного управління розвитком основних напрямів транскордонного співробітництва шляхом створення концептуально оновлених прагматичних організаційно-правових та інституціональних механізмів, адаптованих до правових стандартів системи права $\mathrm{CC}$ - acquis communautaire $\mathrm{CC}$.

\section{СПИСОК ВИКОРИСТАНИХ ДЖЕРЕЛ}

1. Corey M. Johnson. Cross-Border Regions and Territorial Restructuring in CentralEurope. doi: 10.1177/0969776409102190 European Urban and Regional Studies April 2009 vol. 16 no. 2 177-191. Brussels, 11.3.2003.

2. Eduardo Medeiros1 Cross-Border Cooperation in EU RegionalPolicy: a fair deal? - Access regime: http://edumedcv.no.sapo.pt/docs/fd_em.pdf

3. Eric J.Novotny. Transborder-Data Flows and International Law: A framework for Policy-Oriented Inquiry.-Access regime: http://heinonline.org/HOL/LandingPage?collection

4. Markus Perkmann. Cross-Border Regions in Europe Significance and Drivers of Regional Cross-Border Co-Operation. - Access regime: http://eur.sagepub.com/content/10/2/153.abstract

5. European Neighbourhood \& Partnership Instrument. Strategy Paper. Ukraine. 2007-2013.Indicative Programme 2007-2010. Executive SummaryAccess regime: http://ec.europa.eu/

6. Commission of the European Communities.Brussels, 1.3.2003.COM(2003) 104 final. Communication from the Commision to the Council and the European Parliament.Wider Europe - Neighbourhood: A New Framework for Relations with our Eastern and Southern Neighbours- Access regime: http: //ec.europa.eu/world/enp /pdf/com03_104_en.pdf

7. European Neighbourhood \& Partnership Instrument Cross-Border Cooperation Strategy Paper 2007-2013 Indicative Programme 2007-2010- Access regime: http://ec.europa.eu/world/enp/pdf

8. Budkin Viktor. Ukraine and the Eastern Border of the Euro-pean Union. In: Geopolitical Studies, Vol.12. 2004. Warsaw, Poland

9. Marguliková O., Grusmanová E., Muravský J. Inštitucionálne aspekty cezhraničnej spolupráce $\mathrm{v}$ Slovenskej republike: Vývoj a právne postavenie 
cezhraničných štrukur. Analytická študia. - Br.:Rada Europy, Ministerstvo vnutra SR, 2004. - 181.

10. Tschudi H-M. Promoting transfrontier co-operation: an important factor of democratic stability in Europe. - Strasbourg. 4-6 June 2002.

11. Мікула Н.А. Міжтериторіальне та транскордонне співробітництво: монографія. - Львів: ІРД НАН України, 2004. - 395 с.; Проблеми розвитку транскордонного співробітництва України в умовах розширеного $\mathrm{CC}$ : Монографія / За ред. д.е.н., проф. Н.Мікули, к.е.н., доц. В. Борщевського, к.е.н. Т.Васильціва. - Львів: Ліга Прес, 2009. - 436 с.

12. Артьомов І.В. Транскордонне співробітництво в євроінтеграційній стратегії України: [ монографія] - Ужгород: Ліра, 2009. - 520 с. (серія “ Євроінтеграція: український вимір“. Вип. 13).

13. Устич C.I. Кордон, війна та мир в долі сучасного світу. Тріада життя чи колапсу? - Ужгород: Карпати, 2010.

14. Динис Г.Г. Концептуальні основи транскордонного співробітництва України 3 сусідніми європейськими державами: міжнародно-правовий аспект// Наукові записки «Транскордонне співробітництво у контексті перспектив європейської інтеграції України». Серія «Політичні науки». Острог: В-во Національного університету «Острозька академія». - Вип.4. 2010. - C.20-40.

15. G.Dynys. Conceptual Frameworks of National Legislation Harmonization with the Mechanism of International Legislative Regulation on Transborder Relations. - Geopolitics of Ukraine: history and modern times: collection of scientific papers. Issues 5. - Uzhgorod: ZakSU, 2011. - C.82 - 104.

16. Dynys G.G. The effectiveness of International Legal Regulatory Mechanism and Globalization Processes During Economical Crises// Globalization and Crises in Modern Economy. The first scientific volume. Edited by Vitautas Juscius, Lithuania. - 2010. - P.41-52.

17. Кіш Є. Транскордонне співробітництво та регіональна політика Європейського Союзу // На шляху до Європи. Український досвід Єврорегіонів. - Київ: Логос, 2000. - С. 13 - 34.

18. Студенніков Ігор. Транскордонне співробітництво як дзеркало регіональної політики в Україні. - Економічний Часопис-XXI №1-2'2005 Режим доступу: www.niss.od.ua/p/21.doc.

19. Долішній М.І., Бєлєнький П.Ю. Транскордонне співробітництво регіонів у контексті інтеграції України в СС // Проблеми економічної інтеграції України в Свропейський Союз: теорія і стратегія: збірник текстів виступів міжнародної наукової конференції - Львів: Діло Лтд, 1996. - С. 157 158.

20. Федан Р. Регіональні чинники активізації транскордонного співробітництва Польщі та України: монографія. - Львів: ІРД НАН України, 2003. $-336 \mathrm{c}$. 
21. European Outline Convention Transfrontier co-operation between Communities or Authorities. Madrid, 21.Y.1980.- Access regime: http://conventions.coe.int /Treaty/en/treaties/html/106.htm.

22. Угода про створення Співдружності Незалежних Держав. Дата підписання Україною: 08.12.91 р. Дата ратифікації : 10.12.91 р. Дата набуття чинності: 10.12.91 p. http://search.ligazakon.ua/l_doc2.nsf/link1/MU91039R.html Заява Верховної Ради України $з$ приводу укладення Україною Угоди про Співдружність Незалежних Держав. (Відомості Верховної Ради України (BВP), 1992, N 13, ст. 180).

23. Закон України «Про транскордонне співробітництво» від 24.06.2004 p. № 1861-IV (Відомості Верховної Ради (ВВР), 2004, N 45, ст.499).

24. Розпорядження Кабінету Міністрів України. «Про схвалення Концепції Державної програми розвитку транскордонного співробітництва на 2011-2015 роки».

25. Закон України «Про місцеве самоврядування в Україні» (Відомості Верховної Ради України (ВВР), 1997, N 24, ст.170 ). \{ Із змінами, внесеними згідно із Законом N 163-XIV ( 163-14 ) від 06.10.98, ВBР, 1998, N 48, ст.292 \}. Офіційне тлумачення до Закону див. в Рішенні Конституційного Суду N 7рп/99 ( v007p710-99 ) від 06.07.99\}.

26. Закон України «Про місцеві державні адміністрації» (Відомості Верховної Ради України (ВВР), 1999, N 20-21, ст.190). \{ Додатково див. Рішення Конституційного Суду N 6-рп/2007 (v0а6p710-07 ) від 09.07.2007\} \{ Із змінами, внесеними згідно із Законом N 107-VI (107-17) від 12.2007, BBP, 2008, N 5-6, N 7-8, ст.78 - зміни діють по 31 грудня 2008 року \} \{ Додатково див. Рішення Конституційного Суду $\mathrm{N}$ 10-рп/2008 (v010p710-08) від 22.05.2008\}.i N 5059-VI (5059-17 ) від 05.07.2012\}.

27. Model and Outline Agreements, Statutes and Contracts on Transfrontier Co-operation between Territorial Communities or Authorities. - Access regime: http: //conventions.coe.int/Treaty/en/treaties/html/106.htm

\section{REFERENCES}

1 Johnson, C. (2009). Cross-Border Regions and Territorial Restructuring in CentralEurope. European Urban and Regional Studies, 2, 177-191.

2 Medeiros, E. Cross-Border Cooperation in EU RegionalPolicy: a fair deal? Retrieved from: http://edumedcv.no.sapo.pt/docs/fd_em.pdf

3 Novotny, E. Transborder-Data Flows and International Law: A framework for Policy-Oriented Inquiry. Retrieved from: http://heinonline.org/HOL/LandingPage?collection

4 Perkmann, M. Cross-Border Regions in Europe Significance and Drivers of Regional Cross-Border Co-Operation. - Retrieved from: http://eur.sagepub.com/content/10/2/153.abstract 
5 European Neighbourhood \& Partnership Instrument. Strategy Paper. Ukraine. 2007-2013.Indicative Programme 2007-2010. Executive Summary. Retrieved from: http://ec.europa.eu/

6 Commission of the European Communities. Brussels, 1.3.2003.COM(2003) 104 final. Communication from the Commision to the Council and the European Parliament.Wider Europe - Neighbourhood: A New Framework for Relations with our Eastern and Southern Neighbours. Retrieved from: http: //ec.europa.eu/world/enp /pdf/com03_104_en.pdf

7 European Neighbourhood \& Partnership Instrument Cross-Border Cooperation Strategy Paper 2007-2013 Indicative Programme 2007-2010. Retrieved from: http://ec.europa.eu/world/enp/pdf

8 Budkin, V. (2004). Ukraine and the Eastern Border of the European Union. In: Geopolitical Studies, (Vol.12). Warsaw, Poland.

9 Marguliková ,O., Grusmanová, E., \& Muravský, J. (2004).Inštitucionálne aspekty cezhraničnej spolupráce v Slovenskej republike: Vývoj a právne postavenie cezhraničných štrukur [Institutional Aspects of CrossBorder Cooperation in the Slovak Republic: Development and Legal Status of Cross-Border Structures]. Br.:Rada Europy, Ministerstvo vnutra SR.

10 Tschudi, H-M. Promoting transfrontier cooperation: an important factor of democratic stability in Europe. Strasbourg.

11 Mikula, N.A. Borshchevs'kiy, V., \& Vasyl'tsiv, T. (Eds.). (2004). Mizhterytorial'ne ta transkordonne spivrobitnytstvo [Interterritorial and transfrontier co-operation]. L'viv: IRD NAN Ukrayiny.

12 Art'omov, I.V. (2009). Transkordonne spivrobitnytstvo $v$ yevrointehratsiyniy stratehiyi Ukrayiny [Cross-border cooperation in the European integration strategy of Ukraine]. Uzhhorod: Lira.

13 Ustych, S.I. (2010). Kordon, viyna ta myr $v$ doli suchasnoho svitu. Triada zhyttya chy kolapsu? [Border, war and peace in the fate of the modern world. Triad of life or collapse?]. Uzhhorod: Karpaty.

14 Dynys, H.H. (2010). Kontseptual'ni osnovy transkordonnoho spivrobitnytstva Ukrayiny $\mathrm{z}$ susidnimy yevropeys'kymy derzhavamy: mizhnarodno-pravovyy aspekt [Conceptual framework for cross-border cooperation of Ukraine with neighboring European states: the international legal aspect]. Politychni nauky, 4, 20-40. Ostroh: V-vo Natsional'noho universytetu «Ostroz'ka akademiya».

15 Dynys, G. (2011). Conceptual Frameworks of National Legislation Harmonization with the Mechanism of International Legislative Regulation on Transborder Relations. Geopolitics of Ukraine: history and modern times, 5, $82-$ 104. Uzhgorod: ZakSU.

16 Dynys, G.G. (2010). The effectiveness of International Legal Regulatory Mechanism and Globalization Processes During Economical Crises. Globalization and Crises in Modern Economy. 
17 Kish, YE. (2000). Transkordonne spivrobitnytstvo ta rehional'na polityka Yevropeys'koho Soyuzu [Cross-border cooperation and regional policy of the European Union]. Na shlyakhu do Yevropy. Ukrayins'kyy dosvid Yevrorehioniv, 13 - 34. Kyyiv: Lohos.

18 Studennikov I. Transkordonne spivrobitnytstvo yak dzerkalo rehional'noyi polityky v Ukrayini [Cross-border cooperation as a mirror of regional policy in Ukraine]. Ekonomichnyy Chasopys-XXI, 1-2, Retrieved from: www.niss.od.ua/p/21.doc.

19 Dolishniy, M.I., \& Byelyen'kyy, P.YU. (1996). Transkordonne spivrobitnytstvo rehioniv u konteksti intehratsiyi Ukrayiny v YES [Cross-border cooperation of regions in the context of Ukraine's integration into the EU]. Problemy ekonomichnoyi intehratsiyi Ukrayiny v Yevropeys'kyy Soyuz: teoriya i stratehiya. L'viv: Dilo Ltd.

20 Fedan, R. (2003). Rehional'ni chynnyky aktyvizatsiyi transkordonnoho spivrobitnytstva Pol'shchi ta Ukrayiny [Regional factors of activation of crossborder cooperation between Poland and Ukraine]. L'viv: IRD NAN Ukrayiny.

21 European Outline Convention Transfrontier co-operation between Communities or Authorities. Retrieved from: http://conventions.coe.int /Treaty/en/treaties/html/106.htm.

22 Uhoda pro stvorennya Spivdruzhnosti Nezalezhnykh Derzhav [Agreement on the creation of the Commonwealth of Independent States]. Retrieved from: http://search.ligazakon.ua/__doc2.nsf/link1/MU91039R.html

23 Zakon Ukrayiny «Pro transkordonne spivrobitnytstvo» (2004) [The Law of Ukraine "On Transboundary Cooperation"]. Vidomosti Verkhovnoyi Rady.

24 Rozporyadzhennya Kabinetu Ministriv Ukrayiny «Pro skhvalennya Kontseptsiyi Derzhavnoyi prohramy rozvytku transkordonnoho spivrobitnytstva na 2011-2015 roky» [Order of the Cabinet of Ministers of Ukraine. "On Approval of the Concept of the State Program for the Development of Cross-Border Cooperation for 2011-2015"].

25 Zakon Ukrayiny «Pro mistseve samovryaduvannya v Ukrayini» (1997) [The Law of Ukraine "On Local Self-Government in Ukraine"]. Vidomosti Verkhovnoyi Rady Ukrayiny, 24, Art.170.

26 Zakon Ukrayiny «Pro mistsevi derzhavni administratsiyi» (1999) [Law of Ukraine "On Local State Administrations"]. Vidomosti Verkhovnoyi Rady Ukrayiny (VVR), 20-21, Art.190

27 Model and Outline Agreements, Statutes and Contracts on Transfrontier Co-operation between Territorial Communities or Authorities. - Retrieved from: http: //conventions.coe.int/Treaty/en/treaties/html/106.htm 